\title{
Effects of topsoil treatments on afforestation in a dry Mediterranean climate (southern Spain)
}

\author{
Paloma Hueso-González, Juan Francisco Martínez-Murillo, and Jose Damian Ruiz-Sinoga \\ Department of Geography, University of Málaga, Soil and Geomorphology Institute (IGSUMA), \\ Andalucía Tech. Campus de Teatinos s/n, 29071, Málaga, Spain \\ Correspondence to: Paloma Hueso-González (phueso@uma.es)
}

Received: 12 July 2016 - Published in Solid Earth Discuss.: 28 July 2016

Revised: 6 October 2016 - Accepted: 9 October 2016 - Published: 26 October 2016

\begin{abstract}
Afforestation programs in semiarid areas are associated with a high level of sapling mortality. Therefore, the development of alternative low-cost and low-environmentalimpact afforestation methods that ensure the survival of seedlings is crucial for improving the efficiency of Mediterranean forest management. This study assessed the effects of five types of soil amendments on the afforestation success (e.g., plant growth and survival) of a Mediterranean semiarid area. The amendments tested were (i) straw mulch; (ii) mulch containing chipped branches of Aleppo pine (Pinus halepensis L.); (iii) sheep manure compost; (iv) sewage sludge from a wastewater treatment plant; and (v) TerraCottem hydroabsorbent polymer. We hypothesized that in the context of dry Mediterranean climatic conditions, the use of organic amendments would enhance plant establishment and ensure successful afforestation. The results showed that afforestation success varied among the various soil amendment treatments in the experimental plots. The amendments had no effect on soil organic carbon, $\mathrm{pH}$, or salinity, but the results indicated that the addition of mulch or hydroabsorbent polymer can reduce transplant stress by increasing the soil water available for plant growth throughout the hydrological year, and potentially improve the success of afforestation by reducing plant mortality.
\end{abstract}

\section{Introduction}

The combination of climate change, lithology, geomorphology, and human activities has resulted in much of the Mediterranean region being affected by soil and vegetation degradation, which has led to desertification processes (Pérez
Trejo, 1994; Brandt and Thornes, 1996; Puigdefábregas and Mendizábal, 1998; Martínez-Murillo et al., 2016; MuñozRojas et al., 2016a, b; Willaarts et al., 2016). These processes may not be spontaneously reversible, especially in forest environments when certain thresholds are exceeded, as they are necessary to carry out restoration activities (Aronson et al., 1993; Whisenant, 1999).

Vegetation plays a fundamental role in soil conservation (Thornes, 1990; Castillo et al., 1997; Cerdà, 2001; MuñozRojas et al., 2016c). In Mediterranean ecosystems, increasing forest cover has been considered a common technique for mitigating the effects of desertification (Nykvist, 1983; Vallejo et al., 2000; Le Honeuérou, 2000). However, a rapid response of vegetation recolonization could be limited in afforestation proposals due to the climatic conditions of semiarid areas. This can be a consequence of prevailing soil erosion processes and low levels of water and nutrient availability (Breton et al., 2016).

All the environmental factors involved in afforestation processes must be taken into account in determining the responses of plants (Navarro and Palacios, 2004). Burdett (1990) considered that climatic conditions and soil parameters play key roles in the initial stages following transplantation during afforestation. It is assumed that the risk of mortality declines when the period of transplantation stress is passed and physiological attributes return to normal levels (Maestre et al., 2003). Thus, the most important period during afforestation is that during which the plants adjust their morphology and physiology to the new environmental conditions (Maestre and Cortina, 2002a; Maestre et al., 2002b, 2003; Hueso-González et al., 2015; Muñoz-Rojas et al., 2016c). 
In semiarid conditions, revegetation programs are associated with a high level of sapling mortality (Castro et al., 2002). In this context, saplings transplanted to the natural environment are subject to very different conditions than those in the nursery environment (Grossnickle, 2000). Two factors that particularly limit the establishment and growth of seedlings in Mediterranean semiarid environments are (i) excessive radiation and (ii) the limited availability of water during summer droughts (Maestre et al., 2003).

Several studies have investigated various techniques that aimed to increase the survival of seedlings, including irrigation in summer, artificial shade, opening holes large of volume with heavy machinery, and the use of protective cloth (Maestre and Cortina, 2002a). Numerous studies have shown that afforestation success is greater when the above techniques are implemented, especially in the first months following transplantation (Arendt, 1997; Benayas, 1998; Erktan et al., 2016). However, most of these techniques are focused only on seedling protection, and do not involve a holistic view of the environment. Therefore, in the short and medium terms, these techniques are not effective in improving soil quality or reducing soil loss (Rey, 2009; Burylo et al., 2014). In addition, the use of these techniques significantly increases the cost of afforestation. In many cases, they are not applicable because of the topographic conditions (Bochet and García-Fayos, 2004), and they often have major impacts on the ecosystem, which limits their use in areas where landscape conservation is a priority.

For the proper management of Mediterranean forest environments, alternative low-cost afforestation methods that ensure the survival of seedlings and have minimal environmental impact are needed (Eldridge et al., 2012; Benigno et al., 2013). One way to improve soil conditions is to apply organic amendments to the soil. Numerous studies have assessed the use of organic amendments for vegetation establishment and soil fertility, including agricultural soils (Ojeda et al., 2003; Jordán et al., 2010; Jiménez et al., 2013; Tejada and Gonzalez, 2013), eroded soils (Cohen-Fernández and Naeth, 2013; Prats et al., 2016; Donn et al., 2014; Hosseini Bai et al., 2014; Cerdà et al., 2016; Prosdocimi et al., 2016), post-mining soils (Eldridge et al., 2012; Benigno et al., 2013; Muñoz-Rojas et al., 2016b), and afforested soils under Mediterranean conditions (Hueso-González et al., 2014, 2015; Sadeghi et al., 2015).

However, additional studies are needed to assess the effects of soil amendments in afforested areas under Mediterranean semiarid climatic conditions. This study assessed the effects of five types of soil amendments on the afforestation success of a degraded Mediterranean semiarid area. We hypothesized that, in a context of dry Mediterranean climatic conditions, the use of organic amendments could enhance plant establishment and contribute to the afforestation success. The main objectives were to (i) analyze the effect of various organic amendments on main chemical and hydrological soil properties; and (ii) assess the effects of these pa- rameters on the afforestation success, e.g., plant growth and survival under dry Mediterranean climatic conditions.

\section{Materials and methods}

\subsection{Experimental site}

The study was conducted at the El Pinarillo experimental site (X: $424.240 \mathrm{~m} ; Y: 4.073 .098 \mathrm{~m}$; UTM30N/ED50) located in south of Spain (Sierra Tejeda, Almijara y Alhama Natural Park). The surrounded area is characterized by very steep and marble mountains as well as dry Mediterranean climate (mean annual temperature: $18^{\circ} \mathrm{C}$; mean annual rainfall $\left.=589 \mathrm{~mm} \mathrm{yr}^{-1}\right)$. The experimental site is set up in an alluvial fan which was cultivated with cereals until the 1950s. After its abandonment, the area was naturally recolonized by Mediterranean vegetal species of shrubs, mainly Lavandula stoechas L., L. multifida L., Cistus albidus D., Rosmarinus officinalis L., Thymus capitatus L., and Rhamnus alaternus L. Currently, the vegetation cover is higher than $70 \%$ despite a wildfire that occurred in 1991. Due to the previous land use and water erosion processes, soils are eutric Leptosols (FAO-WRB, 2006) featured by a high level of rock fragment cover on the surface $(>50 \%)$, a high gravel content in the profile (total gravel content $=56 \%$; gravel content $>10 \mathrm{~mm}=31 \%$; gravel content $2 \mathrm{f} \mathrm{mm}=10 \%$; gravel content $5 \mathrm{f} 1 \mathrm{~mm}=15 \%$ ), and a sandyloam texture $($ sand $=60 \%$, silt $=32 \%$, clay $=8 \%)$.

\subsection{Plots, amendments, and afforestation}

In the experimental site, considering its homogeneous slope gradient $(7.5 \%)$ and aspect $\left(170^{\circ} \mathrm{N}\right)$, an experimental paired plot layout was performed (12 plots; size: $2 \mathrm{~m}$ width $\times 12 \mathrm{~m}$ length; $24 \mathrm{~m}^{2}$ ). The natural vegetation cover was removed within the experimental plots to preserve similar and initial ecogeomorphic conditions across plots. Afterwards, in May 2011, five amendments and treatments were added to soils in 10 out of the 12 paired replicated plots at an application rate of $10 \mathrm{Mg} \mathrm{ha}^{-1}$. These treatments consisted of straw mulching (SM), mulch composed of chipped branches of Aleppo pine (Pinus halepensis L.) (PM), sheep manure compost $(\mathrm{SH})$, sewage sludge from a wastewater treatment plant (RU), and TerraCottem hydroabsorbent polymer (HP). Two control plots $(\mathrm{C})$ with no amendments were used and considered as afforested in natural conditions.

In November 2011, an afforestation plan was performed in these 12 plots following the same pattern of plantation in each of them (similar spatial pattern and vegetal species). The afforestation plan considered the same vegetal species that the managers from the natural park usually planted in their afforestation management. The plant species used were L. stoechas, L. dentata, L. multifida, R. officinalis, and T. capitatus. Plants were selected from a local nursery and were adapted to the type of environment under study. Then plants 
were transplanted in a grid pattern at a spacing of $0.5 \mathrm{~m}$ between plants in each plot. During the afforestation process the soil was tilled to $25 \mathrm{~cm}$ depth from the surface.

\subsection{Monitoring of vegetation}

Seedlings were assessed twice per year in the period 20112014: (i) 6 months following transplantation (May 2012); (ii) 12 months following transplantation (November 2012); (iii) 20 months following transplantation (June 2013); and (iv) 30 months following transplantation (May 2014). This frequency enabled assessment of growth and development of the plants during the dry and wet Mediterranean seasons, and to evaluate the effect of climatic (temperature and rainfall) and soil parameters including soil salinity (electrical conductivity: EC), soil organic carbon (SOC), and $\mathrm{pH}$.

The number of surviving plants was determined during the field surveys, and the phenological state of plants was measured according to the criteria of Castro et al. (2002) and Gómez-Aparicio et al. (2004). A seedling was considered to be alive if living leaves, buds, or stems were observed. The plant height was measured from the ground to the terminal bud of the tallest stem. The maximum diameter of the canopy was also measured.

\subsection{Soil analysis and measurements}

Soil from the 12 afforested plots was sampled in October 2010 and at 30 months following transplantation. Four samples were collected from each plot (48 soil samples in total) from the soil surface, e.g., $0-10 \mathrm{~cm}$, in which according to Pierce et al. (1994), most soil transformations occur. Soil properties analyzed were (i) EC, performed from deionized water suspension of soil particles (5:1), Crisol Micro CM 2200 conductivity meter (ISRIC, 2002); (ii) pH, obtained from deionized water suspension of the soil $(2.5: 1)$ using a Crisol GLP $21 \mathrm{pH}$ meter; (iii) SOC, determined by means of the Walkley-Black method (FAO, 2006); and (iv) water holding capacity (WHC), which was determined using a sand box ( $\mathrm{pF}$ 2.0) and a Richards membrane ( $\mathrm{pF}$ 4.2) (Richards, 1947; Stakman et al., 1969; Martínez-Fernández et al., 1995). We measured the wilting point (WP) and field capacity (FC) to assess the soil hydrological status during the hydrological year, and its potential relationship to the water available for plants (AWC) (Caldwell, 1976).

Soil moisture probes (HOBO S-SMx-M005) were installed within every amended and not amended paired plot. Two probes were inserted into the soil profile in the middle of each plot at 5 and $10 \mathrm{~cm}$ depths. The total number of probes was 24 in the experimental area. Soil moisture was monitored and recorded at $10 \mathrm{~min}$ intervals. Soil depth was selected according to Hueso-González et al. (2015) based on the limited development of the root systems in depth by the afforested plants during the study period. The analysis of the soil water content (SWC) included only the first $10 \mathrm{~cm}$ of soil profile (at 5 and $10 \mathrm{~cm}$ depths).

\subsection{Statistical analysis}

Normality and variance homogeneity were verified by Kolmogorov-Smirnov and Levene's tests, respectively. In all the analyses, the selected significance limit was $P<0.05$. Plant growth and plant survival data were non-normal following different distributions and requiring nonparametric analysis. These parameters were then measured 30 months after plantation using generalized linear mixed models (GLMs, Bólker et al., 2009) that allowed the analysis of both fixed effects (soil treatment, specie) and random effects (plots). Tukey's post hoc test was used to identify significant differences in growth $(P<0.05)$ among amendments for each plant species. Nonparametric Kruskal-Wallis tests were used for plant variables that did not meet the assumptions of normality and variance homogeneity.

Differences in soil properties were tested using analysis of variance (one-way ANOVA). The assumption of homoscedasticity was tested using Levene's test. In cases of non-homoscedasticity (Levene's test; $P<0.05$ ), nonparametric tests were used. Mean differences between the various experimental soil treatments were determined using Tukey's test or the Games-Howell test. In all analyses the selected significance limit was $P<0.05$. Analyses were performed using SPSS software (version 21) for Windows (IBM Corp. 2012 release).

\section{Results and discussion}

\subsection{Plant establishment and differences in survival rates}

Figure 1 shows the plant survival rates during the study period (2011-2014). According to our results, independently of the amendment applied, most mortality occurred during the first summer, e.g., between 6 and 12 months after plantation (Figs. 1 and 2). Plant stress has been defined in this context as the physiological stress suffered by the sapling due to the limitation of nutrients and water after transplantation (Grossnickle, 2000). In Mediterranean semiarid regions with summer drought or very little rainfalls during this season, this stress could be responsible of the initial increase in plant mortality due to the limited root development of the saplings and their inability to access water contained in the lower layers of the soil profile (Maestre and Cortina, 2002a; Maestre et al., 2002b; Bochet et al., 2007). According to Haase and Rose (1993) soil preparation in these regions could be a powerful tool for reducing the possible plant stress suffered during the lack of water in summer. Several studies have demonstrated that the supply of organic materials could enhance the establishment of young plants and, in some cases, reduce the mortality rates in the initial stages (Woods et al., 2012; Be- 


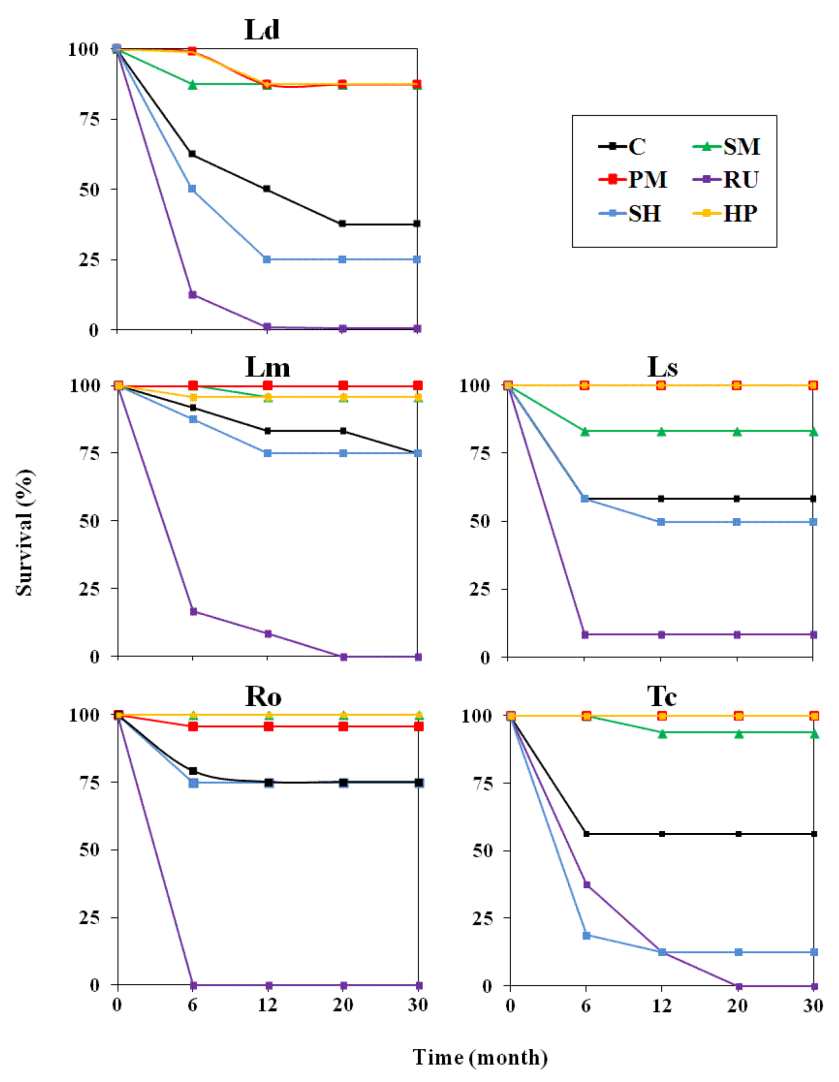

Figure 1. Survival rates $(\%)$ between amendments and control in the period 2011-2014. C: soil afforested and not amended; PM: mulch with chipped branches of Aleppo pine (Pinus halepensis L.); SM: straw mulch; RU: sewage sludge; SH: sheep manure compost; HP: TerraCottem hydroabsorbent polymers; Ls: Lavandula stoechas; Lm: Lavandula multifida; Ld: Lavandula dentata; Ro: Rosmarinus officinalis; Tc: Thymus capitatus.

nigno et al., 2013; Hosseini Bai et al., 2014; Breton et al., 2016).

Our results showed a significant effect of the type of plant species (Table 1a; $P=0.008$ ) and soil amendment (Table 1a; $P=0.000$ ) on plant survival rates. Firstly, a positive effect on survival rates for all species was significantly evident in the case of SM, PM, and HP treatments (Table $1 \mathrm{~b} ; P=0.000$, $P=0.000$, and $P=0.000$, respectively). The highest survival rates were observed for Lavandula dentata and Thymus capitatus which exceeded $40 \%$ in comparison to the control (Fig. 1). The other species presented intermediate results, with an increase of 20-25\% compared to the control. Secondly, a decrease of the survival rates was registered for those plants on soil amended with SH or RU. In these plots, the results showed a negative effect for the sapling establishment. Specifically, non-significant differences in survival rates were obtained during tests for $\mathrm{SH}$ compared to control plots (Table 1b). Thus, plant survival slightly decreased ( $L$. dentata, L. stoechas, or Thymus capitatus) or remained con-

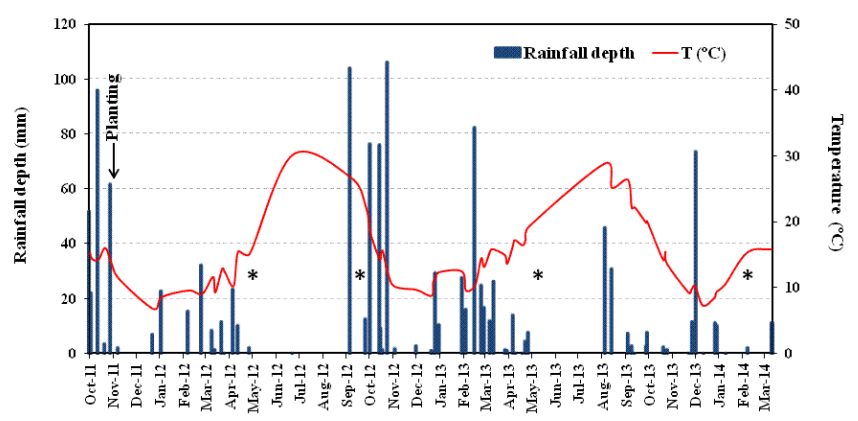

Figure 2. Temporal variability in rainfall and temperature from October 2011 to March 2014. The * symbol indicates the plant monitoring dates.

stant (L. multifida and Rosmarinus officinalis) depending on the plant species (Fig. 1).

With the use of RU, a more critical effect was obtained than with $\mathrm{SH}$ as significant differences were noted on survival rates compared to the control plots $(P=0.000$; Table $1 \mathrm{~b}$ ) and the survival rates approached $0 \%$ independently of the plant species tested. Therefore, these data were removed for further analysis. These results were probably a consequence of the growth of herbaceous plants, named Carlina hispanica, which entirely covered the RU plots after the first wet season (Fig. 5). Its root system is rhizomatous and overwintering buds at $1-10 \mathrm{~cm}$ depth in the soil profile were observed during the field surveys. It is likely to be highly water absorbent and responsible for the mortality of the afforested saplings (Wahrmund et al., 2010).

\subsection{Plant establishment and differences in plant growth (diameter and height)}

In relation to the growth of young plants, significant effects were observed (i) for soil amendment with respect to diameter and height (Table 1a; $P=0.000 ; P=0.000$, respectively) and (ii) for plant species with regard to height only (Table 1a; $P=0.000)$. Furthermore, we found marked differences in plant growth depending of the species and amendment used (Table 1b). Thus, independently of the plant species, differences in plant architectural form (height and diameter) were obvious and significant for SM (Table $1 \mathrm{~b} ; P=0.049$ and $P=0.007$, respectively) and PM (Table $1 \mathrm{~b} ; P=0.002$ and 0.040 , respectively) in contrast to $\mathrm{SH}$ or RU (Table 1b). In the HP plots, significant differences in diameter and height were shown depending on the specie used (Figs. 3 and 4).

The specific differences tested with diameter and height for each plant species showed significant differences in $\mathrm{La}$ vandula sp. and Thymus capitatus after SM, PM, and HP were added (Figs. 3 and 4) and an increase in maximum canopy diameter was registered for most of afforested species (Fig. 4). Significant differences were observed in L. stoechas, L. multifida, L. dentata, and Thymus capitatus (Fig. 4; oneway ANOVA; $P<0.050)$. Also, concerning maximum termi- 


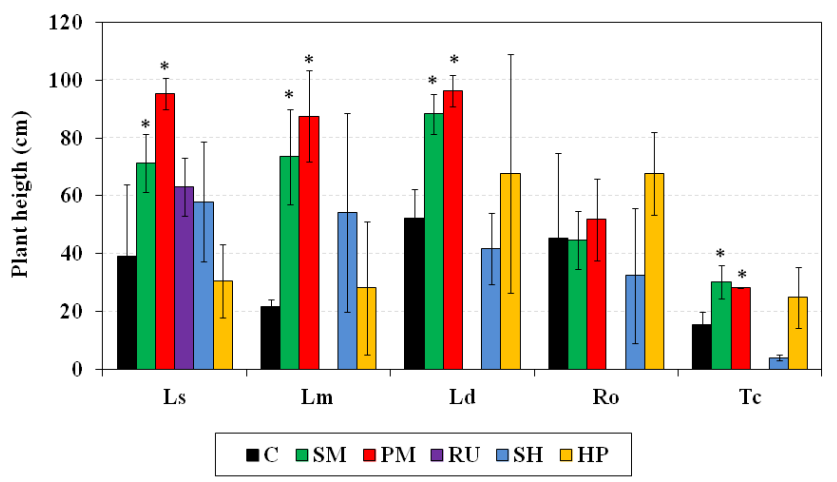

Figure 3. Plant height from ground to terminal bud of the tallest stem (in centimeters) 30 months following transplantation (May 2014). C: soil afforested and not amended; SM: straw mulch; PM: mulch with chipped branches of Aleppo pine (Pinus halepensis L.); RU: sewage sludge; SH: sheep manure compost; HP: TerraCottem hydroabsorbent polymers; Ls: Lavandula stoechas; Lm: Lavandula multifida; Ld: Lavandula dentata; Ro: Rosmarinus officinalis; Tc: Thymus capitatus. The ${ }^{*}$ symbol indicates a significant difference relative to the control $(\mathrm{C})(P<0.05)$.

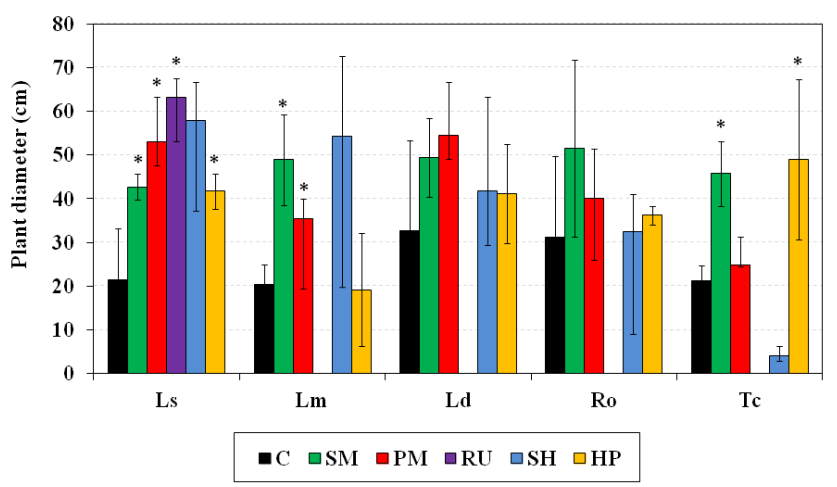

Figure 4. Maximum diameter of the canopy (in centimeters) 30 months following transplantation (May 2014). C: soil afforested and not amended; SM: straw mulch; PM: mulch with chipped branches of Aleppo pine (Pinus halepensis L.); RU: sewage sludge; SH: sheep manure compost; HP: TerraCottem hydroabsorbent polymers; Ls: Lavandula stoechas; Lm: Lavandula multifida; Ld: Lavandula dentata; Ro: Rosmarinus officinalis; Tc: Thymus capitatus. The ${ }^{*}$ symbol indicates a significant difference relative to the control $(\mathrm{C})(P<0.05)$.

nal bud (Fig. 3), a significant positive effect $(P<0.050)$ was also registered for L. stoechas (in SM, PM and HP), L. multifida (in SM and PM), and Thymus capitatus (SM and HP).

\subsection{Soil chemical properties and their impact on plant establishment}

\subsubsection{Changes in SOC}

Changes in SOC were measured in this study to determine whether these reflected differences in the afforested vege-
Table 1. (a) Vegetation measurement: likelihood ratio test for fixed effects on fixed effects soil treatment in species based on generalized mixed effect models (GLMs) for plant survival and growth 30 months after the afforestation. (b) Post hoc multiple comparison for observed means (Tukey's test; $P<0.05$ ). SM: straw mulch; PM: mulch with chipped branches of Aleppo pine (Pinus halepensis L.); RU: sewage sludge; SH: sheep manure compost; HP: TerraCottem hydroabsorbent polymers.

\begin{tabular}{lrc}
\hline (a) & & \\
\hline Effect & $X^{2}$ & $P$ value \\
\hline Survival & & \\
Soil amendment & 43.94 & $\mathbf{0 . 0 0 0}$ \\
Species & 13.73 & $\mathbf{0 . 0 0 8}$ \\
Growth in height & & \\
Soil amendment & 61.38 & $\mathbf{0 . 0 0 0}$ \\
Species & 38.79 & $\mathbf{0 . 0 0 0}$ \\
Growth in diameter & & \\
Soil amendment & 64.66 & $\mathbf{0 . 0 0 0}$ \\
Species & 07.92 & 0.094 \\
\hline
\end{tabular}

\begin{tabular}{lrrrrr}
\hline (b) & & & & & \\
\hline & SM & PM & RU & SH & HP \\
\hline Survival & $\mathbf{0 . 0 0 0}$ & $\mathbf{0 . 0 0 0}$ & $\mathbf{0 . 0 0 0}$ & 0.079 & $\mathbf{0 . 0 0 0}$ \\
Growth in height & $\mathbf{0 . 0 4 9}$ & $\mathbf{0 . 0 0 2}$ & 0.197 & 0.998 & 0.909 \\
Growth in diameter & $\mathbf{0 . 0 0 7}$ & $\mathbf{0 . 0 4 0}$ & 0.089 & 1.000 & 0.357 \\
\hline
\end{tabular}

$P$ values in bold indicate a significant effect $(<0.05)$.

tation at the end of the study period. SOC can be a limiting factor for plant establishment in semiarid lands with degraded soils (Almendros et al., 2010; Hueso-González et al., 2014). Under these conditions, larger rates of plant survival can be expected when soils are amended with external sources of organic matter (Jordán et al., 2010, 2011; Chaudhuri et al., 2015; Shazana et al., 2013; Srinivasarao et al., 2013). In fact, the addition of soil organic matter by means of crop residues such as mulch, sewage sludge, or animal manure can enhance vegetation growth and cover (Montgomery et al., 2007; Ferreras et al., 2006; Franco-Otero et al., 2011; González-Ubierna et al., 2012).

Our results showed that there were no significant differences in SOC in the case of SM, PM, RU, SH, and HP treatments compared to the control $(P \geq 0.050) 30$ months after the amendment addition (Table 2). There was a low rate of mineralization of these organic amendments most likely because of three main factors: (i) the lack of previous composting in the treatments added, which increased the time needed for decomposition processes to occur (García-Gomez et al., 2005); (ii) the high content of lignin and cellulose in the amendments used (Duryea et al., 1999; Jensen, 2009); and (iii) the medium-high rates applied $\left(10 \mathrm{Mg} \mathrm{ha}^{-1}\right)$ (Young et al., 2015). Jordán et al. (2010) showed that mineralization rates in a cultivated area in southwestern Spain were higher when amendments were applied at low rates $\left(3-5 \mathrm{Mg} \mathrm{ha}^{-1}\right)$. González-Ubierna et al. (2012) achieved similar results when 
Table 2. Soil organic carbon (SOC), soil acidity $(\mathrm{pH})$, and soil salinity (EC) (mean and standard deviation (SD), $n=8$ ) measured 30 months after the plots' afforestation. C: soil afforested and not amended; PM: mulch with chipped branches of Aleppo pine (Pinus halepensis L.); SM: straw mulch; RU: sewage sludge; SH: sheep manure compost; HP: TerraCottem hydroabsorbent polymers. The * symbol indicates a significant difference compared to the control (C) $(P<0.05)$.

\begin{tabular}{lrrrrrrr}
\hline & \multicolumn{4}{c}{ SOC $(\%)$} & \multicolumn{2}{c}{$\mathrm{pH}$} & \multicolumn{2}{c}{$\mathrm{EC}\left(\mu \mathrm{S} \mathrm{cm}^{-1}\right)$} \\
\cline { 2 - 8 } & $n$ & Mean & SD & Mean & SD \pm & Mean & SD \pm \\
\hline C & 8 & 3.00 & 0.40 & 7.70 & 0.00 & 374.00 & 31.50 \\
PM & 8 & 2.90 & 0.20 & 7.50 & 0.10 & 402.70 & 60.70 \\
SM & 8 & 2.50 & 0.20 & 7.60 & 0.00 & 385.20 & 54.50 \\
RU & 8 & 3.30 & 0.20 & $7.40^{*}$ & 0.10 & $507.20 *$ & 91.70 \\
SH & 8 & 3.70 & 0.40 & 7.70 & 0.00 & 389.20 & 111.80 \\
HP & 8 & 2.90 & 0.60 & 7.60 & 0.10 & 370.90 & 97.20 \\
\hline
\end{tabular}

testing differences in SOC after the additions of three test organic residues. Hueso-González et al. (2014) reported that more than 30 months were needed to detect the effect of these amendments on SOC values.

\subsubsection{Changes in soil pH and EC}

Changes in soil $\mathrm{pH}$ and $\mathrm{EC}$ were measured to determine whether these parameters reflected differences in growth of the afforested vegetation at the end of the study period (Table 2). Guang-Ming et al. (2006) and Li et al. (2007) showed that the application of certain organic amendments could cause a change in the $\mathrm{pH}$ and a slight increase in EC. Similarly, Parida and Das (2005) showed that variations in salinity or acidity can affect plant growth and survival rates. Allakherdiez et al. (2000) reported that plants adversely affected by salinity grew more slowly and were stunted. Some studies have reported that changes on soil salinity and acidity during afforestation may cause sapling mortality (Ferreras et al., 2006; Guang-Ming et al., 2006). According to other authors, there is not a direct relationship between the amendment addition and the increment in soil salinity or acidity (Ferreras et al., 2006) and these changes depend on the type and application rate of amendment as well as the climatic conditions (Li et al., 2007; Hueso-González et al., 2014). In our study, amendments were applied mixed with soil at the rate of $10 \mathrm{Mg} \mathrm{ha}^{-1}$ and no significant differences were found compared to the control plots (Table 2). We only detected significant differences in the RU treatment 30 months after the afforestation (Table 2; $P>0.005$ ). However, based on previous studies, the measured changes were not sufficient to cause the mortality of the afforested plants (Ferreras et al., 2006; Guang-Ming et al., 2006; Li et al., 2007).

In summary, a positive effect on afforestation performance, e.g., plant growth and survival, was evidenced when the soil was amended with SM, PM, and HP, and no benefits were noted with SH and RU additions (Table 1 and Figs. 1,
3 , and 4). However, the lack of differences found in SOC, $\mathrm{pH}$, or EC among treatments could not justify the differences in survival rates and plant growth previously described (Table 2).

\subsection{Available water for plants and their impact on vegetation establishment}

We tested differences in SWC between the amendment and the control plots. The relation of SWC with WHC was also analyzed during the study period in order to identify the number of months with available water for plants and their relation with plant growth and establishment (Table 3 and Fig. 6). In the control plots the average SWC was $07.0 \pm 06.0 \%$ and $04.0 \pm 05.0 \%$ at 5 and $10 \mathrm{~cm}$ depths, respectively. However, high coefficients of variation were found (CV > 80.0\%) which indicates a likely effect of the rainfall seasonality under Mediterranean climatic conditions affecting the variability in SWC (Fig. 2). Several studies have shown that inadequate soil water storage is the major limiting factor for the sapling establishment in semiarid areas (Haase and Rose, 1993; Whisenant et al., 1999; South, 2000; HuesoGonzález et al., 2015; Muñoz-Rojas et al., 2016c), and others have reported new techniques needed to increase the AWC in dryland soils (Tongway and Ludwing, 1996; Shachak et al., 1998). Ros et al. (2006) showed that the addition of amendments (urban organic waste, green waste, manure, and sewage sludge) favored the development of vegetation cover in Spain because of increased soil moisture. Accordingly, Hueso-González et al. (2015) reported an increase in SWC following the addition of organic mulching to soils due to a larger increase in the macro-porosity.

The low survival rates found in the control (Fig. 1) can be explained by the Mediterranean seasonality (Fig. 2), which comprised heavy rainfall and long dry spells in the initial months after the afforesting proposal (Donn et al., 2014; Hueso-González et al., 2015; Young et al., 2015). Bochet and García-Fayos (2004) reported similar results in a study involving Mediterranean slope areas. Generally, during the study period, SWC for sapling growth was below the wilting point (WP) for 6 months each year (Fig. 6). The seedling roots might have taken up the water held in the soil at the beginning of the first dry season resulting in a soil rapidly becoming dry and, consequently, in a shortage of available water for plants (Fig. 6). Additionally, maximum evaporation processes usually take place during the following months (in the summer period) due to the high temperatures and the absence of rainfall. This may explain the fact that most mortality found in the control plots (Fig. 2) occurred during the summer period of the first year.

In plots that received soil amendments, two contrasted patterns of AWC were observed (Fig. 6). Soils in the SM, PM, $\mathrm{HP}$, and RU plots presented higher AWC than in the control plots, whereas lower AWC was measured in the soils treated with SH. In general terms, the trends observed matched with 

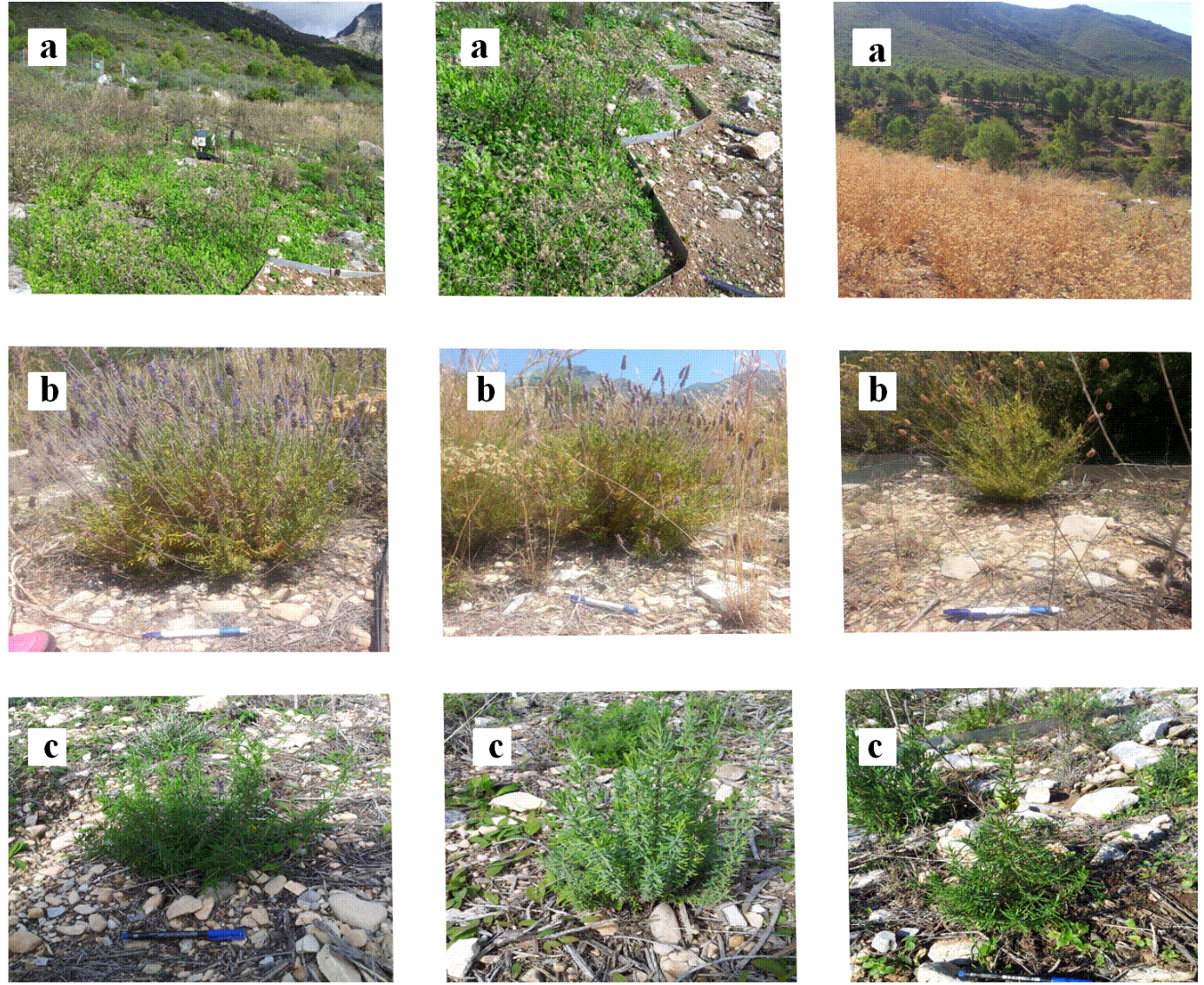

Figure 5. Photos of the experimental plots. From left to right: (a) plots amended with sewage sludge covered by Carlina hispanica Lam. in May 2012, June 2012, and September 2012, respectively; (b) Lavandula dentata individuals, June 2013, for straw mulch, pine mulch, and hydroabsorbent polymer plots, respectively; (c) Rosmarinus officinalis individuals, June 2013, for straw mulch, pine mulch, and hydroabsorbent polymer plots, respectively.

Table 3. Annual soil water content (\%) at 5 and $10 \mathrm{~cm}$ profile depths (mean, SD, coefficient of variation (CV), and maximum value (max)). The study period lasted from October 2011 to March 2014. C: soil afforested and no amendment; PM: mulch with chipped branches of Aleppo pine (Pinus halepensis L.); SM: straw mulch; RU: sewage sludge; SH: sheep manure compost; HP: TerraCottem hydroabsorbent polymers.

\begin{tabular}{|c|c|c|c|c|c|c|c|c|c|}
\hline \multirow[b]{2}{*}{ Treatment } & \multicolumn{5}{|c|}{ Depth $5 \mathrm{~cm}(\%)$} & \multicolumn{4}{|c|}{ Depth $10 \mathrm{~cm}(\%)$} \\
\hline & $\mathrm{N}$ & Mean & $\mathrm{SD} \pm$ & $\mathrm{CV}(\%)$ & Max & Mean & $\mathrm{SD} \pm$ & $\mathrm{CV}(\%)$ & Max \\
\hline $\mathrm{C}$ & 2 & 7.00 & 6.00 & 85.71 & 26.00 & 4.00 & 5.00 & 125.00 & 20.00 \\
\hline SM & 2 & 8.00 & 7.00 & 87.50 & 23.00 & 7.00 & 5.00 & 71.43 & 22.00 \\
\hline PM & 2 & 7.00 & 6.00 & 85.71 & 22.00 & 6.00 & 5.00 & 83.33 & 21.00 \\
\hline HP & 2 & 10.00 & 7.00 & 70.00 & 31.00 & 5.00 & 6.00 & 120.00 & 21.00 \\
\hline RU & 2 & 9.00 & 6.00 & 66.67 & 25.00 & 4.00 & 5.00 & 125.00 & 22.00 \\
\hline SH & 2 & 8.80 & 7.00 & 87.50 & 23.00 & 5.00 & 4.00 & 80.00 & 20.00 \\
\hline
\end{tabular}

the patterns previously reported for survival rates and plant growth (diameter and height) (Table 1 and Figs. 1, 3, and 4).

$\mathrm{SM}, \mathrm{PM}, \mathrm{RU}$, and HP treatments showed an increase in the average SWC with respect to the control conditions (Table 3). Thus, Fig. 6 shows that the AWC in soils amended with SM, PM, RU, or HP was higher than in the control during most of the duration of the experiment and, consequently, there was less water stress following afforestation. This was well related to the increment in sapling survival rates found in the SM, PM, and HP treatments (Table $1 \mathrm{~b}$, $P=0.000$, and Fig. 1). Similar results were reported by Breton et al. (2016) in a study of soil amended with wood chips, 


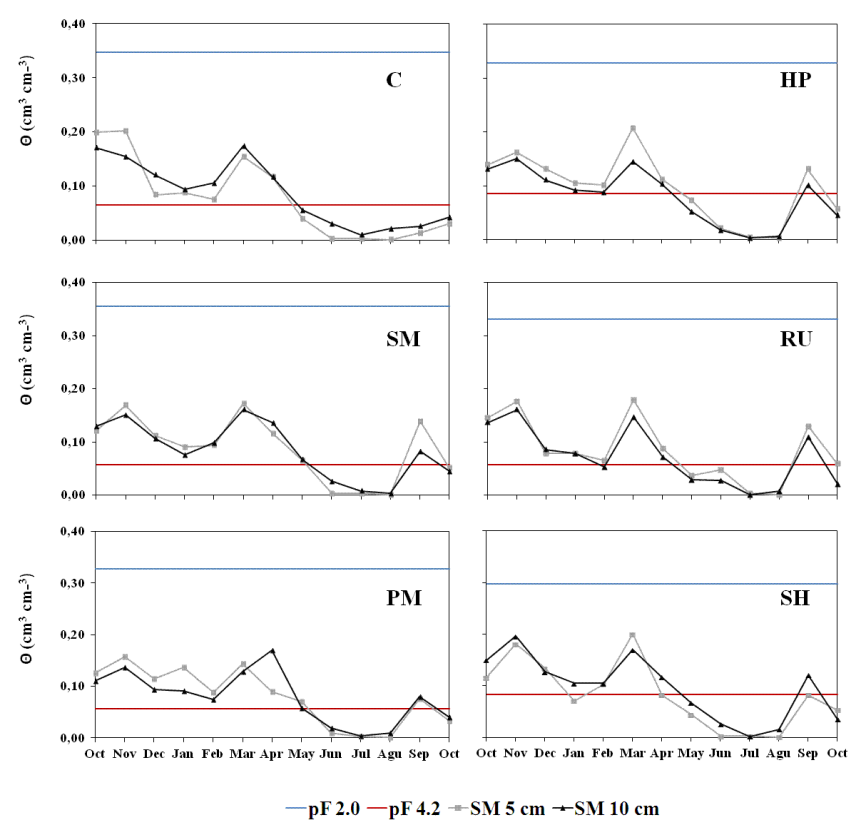

Figure 6. Soil moisture trends under different treatments and their relations to water retention capacity. $\mathrm{pF} 2.0$ : field capacity; $\mathrm{pF} 4.2$ : wilting point; C: control; SM: straw mulch; PM: chipped branches of Aleppo pine; HP: TerraCottem hydroabsorbent polymers; RU: sewage sludge; $\mathrm{SH}$ : sheep manure.

where survival rates increased by $30 \%$. The results are also consistent with those of Querejeta et al. (2001) and Castillo et al. (2001), who reported that revegetation programs in semiarid conditions needed previous soil preparation for increasing water availability for plants. Figures 3 and 4 show the effect of AWC on plant height and maximum diameter in the PM, SM, and HP plots. Compared to the control, plots amended with PM and SM also showed significant differences in plant growth (height and diameter) (Table $1 \mathrm{~b}$, $P=0.000 ; P=0.000 ; P=0.002 ; P=0.040$, respectively). In the SM and PM plots SWC remained relatively constant with depth (Table 3) and the CV at $10 \mathrm{~cm}$ depth was low, reflecting greater stability in the SWC during the hydrological year. This indicated that soil moisture remained higher in the profile, especially, during the dry Mediterranean drought period which may be related to higher AWC following amendment addition (Fig. 6), and may be similar to the effect described by Calvo et al. (2003) and Gabarrón-Galeote et al. (2013). In this study, the addition of mulch caused an increase in soil roughness and macro-porosity, which may have amplified infiltration processes (Hueso-González et al., 2015). Adekalu et al. (2007) and Jordán et al. (2010) reported a reduction in soil evapotranspiration resulting from the protective effect of mulching. Nevertheless, in this study we could not establish differences between the effects of the SM and PM treatments because the survival rates and the plant growth were quite similar (Figs. 1, 3, 4, and 5).
Regarding RU, AWC for plants in these plots was higher than in the control (Fig. 6). However, the survival rates were close to $0 \%$ (Fig. 1). In the RU plots, although there was vegetation cover of $100 \%$, it was caused by an invasive nitrophilous grassland species introduced with the sewage sludge amendment (Fig. 5), even though the RU plots had been transplanted with the same number of plants and using the same spatial pattern of Mediterranean shrubs as in the other treatments. Previous studies at the experimental site indicated that this exogenous nitrophilous grassland outcompetes the afforestation species for nutrients and water (Hueso-González et al., 2015), and this explains the high mortality measured in the RU plots. Guerrero et al. (2001) and Ojeda et al. (2003) measured a change in the ammonium and nitrite content in agricultural soils following sewage sludge application, and interpreted this as resulting from an increase in soil salinity that reduced the number of nitrifying bacteria. At the end of our study, very few $L$. stoechas and $T$. capitatus plants remained in the RU plots (Fig. 1).

The SH amended plots showed the opposite effect on SWC and WHC than SM, PM, RU, and HP plots. The AWC was lower during the study period (Table 3 and Fig. 6) and below the wilting point for more than 5 months of every year, from April to August, coinciding with the highest temperature and evapotranspiration values (Fig. 2). Consequently, plants suffered a lack of water entering into the soil and this stress resulted in higher mortality rates (Fig. 1). This period of water stress, below the WP, was between April and August, at the same time as the Mediterranean dry period in which maximum temperatures and minimum rainfall occurred (Fig. 2). As a result, plant survival rates measured in this treatment were lower than in the other treatments (Table 1 and Fig. 1). In addition, the pattern of AWC in the SH treatment was similar to that found in the control plots (Fig. 6). This also explains the similarities, and not significant differences, in plant height and maximum diameter in the control and the SH treatment plots (Table $1 \mathrm{~b}, P=0.197 ; P=0.089$, respectively).

\section{Conclusions}

i. Under dry Mediterranean climate conditions, the afforestation success (e.g., plant growth and survival) varied depending on the amendments applied to the soil in the experimental plots.

ii. The amendments, applied to the soil to improve plant survival, did not cause significant changes to the soil organic carbon content, $\mathrm{pH}$, or electrical conductivity.

iii. Significant differences in the water available for plants occurred among the various soil amendment treatments, with the straw mulch, Aleppo pine, and TerraCottem hydroabsorbent polymer treatments having very positive effects on plant growth. 
iv. In terms of land management, this study shows that the addition of mulch or hydroabsorbent polymer can reduce transplanting stress and improve the success of afforestation programs by reducing the mortality of plants.

Acknowledgements. The study was funded by the P09-RNM-5057 research project (autonomous government of Andalusia, Spain) as well as the campus of Andalucia Tech. The authors also thank the TRAGSA company for their technical support during the experimental site setup.

Edited by: M. Muñoz-Rojas

Reviewed by: two anonymous referees

\section{References}

Adekalu, K. O., Olorunfemi, I. A., and Osunbitan, L. A.: Grass mulching effect on infiltration, surface runoff and soil loss of three agricultural soils in Nigeria, Bioresource Technol., 98, 912-917, 2007.

Allakherdiez, S. I., Sakamoto, A., Nishiyama, Y., and Murata, N.: Ionic and Osmotic Effects of NaCL-Induced Inactivation of Photosystems and I and II in Synechococcus sp., Americacan Society of Plant Physiologists, 123, 1047-1056, 2000.

Almendros, G., González-Vila, J., González-Pérez, J. A., Knicker, H., and de la Rosa, J. M.: Protocólos y técnicas para evaluar el impacto del fuego sobre la materia orgánica, edited by: Cerdà, A. and Jordán, A., Actualización en métodos y técnicas para el estudio de los suelos afectados por incendios forestales, 291-319, 2010.

Arendt, J. D.: Adaptive intrinsic growth rates: an interpretation across taxa, Quarterly Rev. Biol, 72, 149-177, 1997.

Aronson, J., Floret, C., LeFolch, E., Ovalle, C., and Pontainer, R.: Restoration and rehabilitation of degraded ecosystems in arid and semiarid lands. I. A view from the south, Restor. Ecol., 1, 8-17, 1993.

Benayas, L. M.: Drougth and survival Quercus ilex L. seedlings after irrigation and artificial shading on Mediterranean set-aside agricultural land, Ann. Sci. Forest., 55, 801-807, 1998.

Benigno, S. M., Dixon, K. W., and Stevens, J. C.: Increasing soil water retention with native sourced mulch improves seedling establishment in postmine Mediterranean sandy soils, Restor. Ecol., 21, 617-626, 2013.

Bochet, E. and García-Fayos, P.: Factors controlling vegetation establishment and water erosion on motorway slopes in Valencia, Spain, Restor. Ecol., 12, 166-174, 2004.

Bochet, E., García-Fayos, P., Alborch, B., and Tormo, J.: Soil water availability effects on seed germination account for species segregation in semiarid roadslopes, Plant Soil, 295, 179-191, 2007.

Bólker, B. M., Brooks, M. E., Clark, C. J., Geange, S. W., Poulsen, J. R., Stevens, M. H. H., and Wite, J.-S. S.: Generalized linear mixed models: a practical guide for ecology and evolution, Trends Ecol. Evol., 24, 127-135, 2009.

Brandt, C. J. and Thornes, J. B.: Mediterranean desertification and Land use, edited by: Brandt, C. J. and Thornes, J. B., John Wiley \& Sons, Chichester, 1996.
Breton, V., Crosaz, Y., and Rey, F.: Effects of wood chip amendments on the revegetation performance of plant species on eroded marly terrains in a Mediterranean mountainous climate (Southern Alps, France), Solid Earth, 7, 599-610, doi:10.5194/se-7599-2016, 2016.

Burdett, A. N.: Physiological processes in plantation establishment and the development of specifications for forest planting stock, Can. J. Forest Res., 20, 415-427, 1990.

Burylo, M., Dutoit, T., and Rey, F.: Species traits as practical tools for ecological restoration on marly eroded lands, Ecological Restoration, 22, 633-640, 2014.

Caldwell, M. M.: Root extension and water absorption, edited by: Lange, O. L., Kappen, L., and Schulze, E. D., Water and plant life. Problems and modern approaches, Springer Verlang, Berlin, 73-86, 1976.

Calvo, A., Boix, C., and Imeson, A. C.: Runoff generation, sediment movement and soil water behaviour on calcareous (limestone) slopes of some Mediterranean environments in Southeast Spain, Geomorphology, 50, 269-291, 2003.

Castillo, V., Querejeta, J., and Albaladejo, J.: Disponibilidad hídrica en repoblaciones de Pinus halepensis Mill. en medios semiáridos: efectos de los métodos de preparación del suelo, III Congreso Forestal Español, Mesa 3, 94-99, 2001.

Castillo, V. M., Martínez-Mena, M., and Albadejo, J.: Runoff and soil erosion response to vegetation removal in a semiarid environment, Soil Sci. Soc. Am. J., 61, 1116-1121, 1997.

Castro, J., Zamorra, R., Hóndar, J. A., and Gómez, J. M.: The use of shrubs as nurse plants: a new technique for reforestation in Mediterranean mountains, Rest. Ecol, 10, 297-305, 2002.

Cerdà, A.: Effects of rock fragments cover on soil infiltration, interrill runoff and erosion, Eur. J. Soil Sci., 52, 59-68, 2001.

Cerdà, A., González-Pelayo, O., Giménez-Morera, A., Jordán, A., Pereira, P., Novara, A., Brevik, E. C., Prosdocimi, M., Mahmoodfabadi, M., Keesstra, S., García Orenes, F., and Ritsema, C.: The use of barley Straw residues to avoid high erosion and runoff rates on persimmon plantations in Eastern Spain under low frequency-high magnitude simulated rainfall events, Soil Res., 54, 154-165, 2016.

Chaudhuri, S., McDonald, L. M., Skousen, J., and Pena-Yewtukhiw, E. M.: Soil organic carbon molecular properties: effects of time since reclamation in a minesoil chronosequence, Land Degrad. Dev., 26, 237-248, doi:10.1002/ldr.2202, 2015.

Cohen-Fernández, A. C. and Naeth, M. A.: Erosion control blankets, organic amendments and site variability influenced the initial plant community at a limestone quarry in the Canadian Rocky Mountains, Biogeosciences, 10, 5243-5253, doi:10.5194/bg-10-5243-2013, 2013.

Donn, S., Wheatley, R. E., Mckenzie, B. M., Loades, K. M., and Hallett, P. D.: Improved soil fertility from compost amendments increases root growth and reinforcement of surface soil on slope, Ecol. Eng, 71, 458-465, 2014.

Duryea, M. L., Jeffery, E. R., and Hermasen, A. L.: Will subterranean termites consume landscape mulches, Journal of arboriculture, 25, 88-97, 1999.

Eldridge, J. D., Redente, E. F., and Paschke, M.: The use of seedbed modifications and wood chips to accelerate restoration of well pad sites in western Colorado, USA, Restor. Ecol., 20, 524-531, 2012. 
Erktan, A., Cécillon, L., Graf, F., Roumet, C., Legout, C., and Rey, F.: Increase soil aggregate stability along a Mediterranean successional gradient in severely eroded gully bed ecosystem: commbined effects of soil, root traits and plant community characteristics, Plant. Soil, 398, 121-137, 2016.

FAO: World reference base for soil resource: A framework for a international classification, correlation and communication, FAO, Roma, 145, 2006.

Ferreras, L., Gómez, E., Torresani, S., Firpo, I., and Rotondo, R.: Effect of organic amendments on some physical, chemical and biological properties in a horticultural soil, Bioresource Technol., 97, 635-640, 2006.

Franco-Otero, V. C., Soler-Rovira, P., Hernández, D., López-DeSá, E., and Plaza, C. S.: Short-term effects of organic municipal wastes on wheat yield, microbial biomass, microbial activity, and chemical properties of soil, Biol. Fert. Soils, 12, 1257-1268, 2011.

Gabarrón-Galeote, M. A., Martínez-Murillo, J. F., Quesada, M. A., and Ruiz-Sinoga, J. D.: Seasonal changes in the soil hydrological and erosive response depending on aspect, vegetation type and soil water repellency in different Mediterranean microenvironments, Solid Earth, 4, 497-509, doi:10.5194/se-4-497-2013, 2013.

García-Gomez, A., Bernal-Calderón, M. P., and Roig, A.: Humification parameters, organic waste management, organic matter, Compost Sci. Util., 13, 127-135, 2005.

Gómez-Aparicio, L., Zamora, R., Gómez, J. M., Hódar, Castro, J., and Baraza, E.: Applying plant facilitation to forest restoration: A meta-analysis of the use of shrubs as nursery plants, Ecol. Appl., 14, 1128-1138, 2004.

González-Ubierna, S., Jorge-Mardomingo, I., Carrero-González, B., De la Cruz, M. T., and Carsermeiro, M. A.: Soil organic matter evolution after the application of high doses of organic amendments in a Mediterranean calcareous soil, Soils and Sediments, 12, 1257-1268, 2012.

Grossnickle, S. C.: Ecophysiology of northernspruce species. The performance of planted seedlings, NCR Research Press, Ottawa, Notario, Canada, 409, 2000.

Guang-Ming, L., Jing-Song, Y., and Rong-Jiang, Y.: Electrical conductivity in soil extracts: chemical factors and their intensity, Pedosphere, 16, 100-107, 2006.

Guerrero, C., Gómez, I., Moral, R., Mataix-Solera, J., MataixBeneyto, J., and Hernández, T.: Reclamation of a burned forest soil with municipal waste compost: macronutrient dynamic and improved vegetation cover recovery, Bioresource Technol., 76, 221-227, 2001.

Haase, D. L. and Rose, R.: Soil moisture stress induces transplant shock in stored and unstored $2+0$ Douglas-Fir seedlings of varying root volumes, Forest Sci., 39, 275-294, 1993.

Hosseini Bai, S., Blumfield, T. J., and Reverchorn, F.: The impact of mulch type on soil carbon and nitrogen pools in a sloping site, Biol. Fert. Soils, 50, 37-44, 2014.

Hueso-González, P., Martínez-Murillo, J. F., and Ruiz Sinoga., J. D.: The impact of organic amendments on forest soil properties under Mediterranean climatic conditions, Land Degrad. Dev., 25, 604-612, 2014.

Hueso-González, P., Ruíz Sinoga, J. D., Martínez-Murillo, J. F., and Lavee, H.: Overland flow generation mechanisms affected by topsoil treatment: Application to soil conservation, Geomorphology, 228, 796-804, 2015.

IBM Corp.: IBM SPSS Statistics for Windows, Version 21.0. Armonk, NY: IBM Corp, 2012.

ISRIC.: Procedures for soil analysis, Technical paper 9, Int Soil Ref and Int Centre, Wageningen, the Netherlands, 2002.

Jensen, H. L.: The microbiology of farmyard manure decomposition in soil II, Decomposition of cellulose, J. Agr. Sci., 21, 81-100, 2009.

Jiménez, M., Fernández-Ondoño, E., Ripoll, M. A., CastroRodríguez, J., Hunsinger, L., and Bruno Navarro, F.: Stones and organic mulches improve the Quercus Ilex L. afforestation success under Mediterranean climatic conditions, Land Degrad. Dev., 27, 357-365, 2013.

Jordán, A., Zavala, L. M., and Gil, J.: Effects of mulching on soil physical properties and runoff under semi-arid conditions in southern Spain, Catena, 81, 77-85, 2010.

Jordán, A., Zavala, L. M., and Muñoz-Rojas, M.: Mulching, effects on soil physical properties, in: Encyclopedia of Agrophysics, edited by: Glinski, J., Horabik, J., and Lipiec, J., Springer, Berlin, 492-496, 2011.

Le Honeuérou, Henry N.: Restoration and rehabilitation of Arid and Semiarid Mediterranean ecosystems in North Africa and West Asia, A review, Arid Soil Res. Rehab., 14, 3-14, 2010.

Li, X., Li, Z., Ding, Y., Liu, S., Zhao, Z., Luo, L., Pang, H., Li, C., Li, H., You, X., and Wang, F.: Seasonal variations of PH and electrical conductivity in a snow-firn pack on Glacier No, 1 , eastern Tianshan, China, Cold. Reg. Sci. Technol., 48, 55-63, 2007.

Maestre, F. T. and Cortina, J.: Spatial patterns of surface soil properties and vegetation in a Mediterranean semi-arid steppe, Plant Soil, 241, 279-291, 2002a.

Maestre, F. T., Huesca, M., Zaady, E., Bautista, S., and Cortina, J.: Infiltration, penetration resistance and microphytic crust composition in contrasted microsites within a Mediterranean semi-arid steppe, Soil Biol. Biochem., 34, 895-898, 2002b.

Maestre, F. T., Cortina, J., Bautista, S., Bellot, J., and Vallejo, V. R.: Small-scale environmental heterogeneity and spatial-temporal dynamics of seedling establishment in a semiarid degraded ecosystem, Ecosystems, 6, 630-643, 2003.

Martínez-Fernández, J., Lopez-Bermudez, F., Martínez-Fernández, J., and Romero-Díaz, M. A.: Land use and soil vegetation relationships in Mediterranean ecosystem: El Ardal, Murcia, Spain, Catena, 25, 153-167, 1995.

Martínez-Murillo, J. F., Hueso-González, P., Ruiz-Sinoga, J. D., and Lavee, H.: Short-Experimental fire effects in soil and water losses in southern of Spain, Land Degrad. Dev., 27, 1513-1522, 2016.

Montgomery, D. R.: Soil erosion and agricultural sustainability, P. Natl. Acad. Sci. USA, 104, 13268-13272, 2007.

Muñoz-Rojas, M., Erickson, T. E., Dixon, K. W., and Merritt, D.: Soil quality indicators to assess functionality of restored soils in degraded semiarid ecosystems, Restor. Ecol., 24, S43-S52, doi:10.1111/rec.12368, 2016a.

Muñoz-Rojas, M., Erickson, T. E., Martini, D., Dixon, K. W., and Merritt, D. J.: Soil physicochemical and microbiological indicators of short, medium and long term post-fire recovery in semiarid ecosystems, Ecol. Indic., 63, 14-22, 2016 b.

Muñoz-Rojas, M., Erickson, T. E., Martini, D. C., Dixon, K. W., and Merritt, D. J.: Climate and soil factors influencing seedling 
recruitment of plant species used for dryland restoration, SOIL, 2, 287-298, doi:10.5194/soil-2-287-2016, 2016c.

Navarro, R. M. and Palacios, G.: Efecto de la calidad de planta, el procedimiento de preparación y la fecha de plantación en la supervivencia de una repoblación de Pinus pinea L., Cuadernos de la SECF, 17, 199-204, 2004.

Nykvist, N.: Soil erosion, The scientific Magazine of Swedish Forestry Association, No. 1/83, 48, 1983.

Ojeda, G., Alcañiz, J. M., and Ortiz, O.: Runoff and losses by erosion in soils amended with sewage sludge, Land Degrad. Dev., 14, 563-573, 2003.

Parida, A. K. and Das, A. B.: Salt tolerance and salinity effects on plants: a review, Ecotox. Environ. Safe., 60, 324-349, 2005.

Pérez Trejo, F.: Desertification and Land degradation in the European Mediterranean. European Commission, DG XVII, Brussels, Belgium, 1994.

Pierce, F. J., Fortin, M. C., and Staton, M., J.: Periodic plowing effects on soil properties in a no-tillage farming system, Soil Sci. Soc. Am. J., 58, 1782-1787, 1994.

Prats, S. A., Malvar, M. C., Vieira, D. C. S., MacDonald, L., and Keizer, J. J.: Effectiveness of hydromulching to reduce runoff and erosion in a recently burnt pine plantation in central Portugal, Land Degrad. Dev., 27, 1319-1333, doi:10.1002/ldr.2236, 2013.

Prosdocimi, M., Jordán, A., Tarolli, P., Keestra, S., Novara, A., and Cerdà, A.: The immediate effectiveness of barley straw mulch in reducing soil erodibility and surface runoff generation in Mediterranean vineyards, Sci. Total Environ., 547, 323-330, 2016.

Puigdefábregas, J. and Mendizábal, T.: Perspectives on desertification: Western Mediterranean, J. Arid Environ., 39, 209-224, 1998.

Querejeta, J., Roldán, A., Albaladejo, J., and Castillo, V.: Soil water availability improved by site preparation in a Pinus halepensis afforestation under semiarid climate, Forest Ecol. Manag., 149, 115-128, 2001.

Rey, F.: A strategy for fine sediment retention with bioengineering works in eroded marly catchments in a mountainous Mediterranean climate (Southern Alps, France), Land Degrad. Dev., 20, 210-216, 2009.

Richards, L. A.: Pressure membrane apparatus: construction and use, Agr. Eng., 28, 451-454, 1947.

Ros, M., Pascual, J. A., García, C., Hernández, T., and Insam, H.: Hydrolase activities, microbial biomass and bacterial community in a soil after long-term amendment with different composts, Soil Biol. Biochem., 12, 3443-3452, 2006.

Sadeghi, S. H. R., Gholami, L., Homaee, M., and Khaledi Darvishan, A.: Reducing sediment concentration and soil loss using organic and inorganic amendments at plot scale, Solid Earth, 6, 445-455, doi:10.5194/se-6-445-2015, 2015.

Shachak, M., Sachs, M., and Moshe, I.: Ecosystem management of desertied scrubslands in Israel, Ecosystem, 1, 475-483, 1998.
Shazana, M. A. R. S., Shamshuddin, J., Fauziah, C. I., and Syed Omar, S. R.: Alleviating the infertility of an acid sulphate soil by using ground basalt with or without lime and organic fertilizer under submerged conditions, Land Degrad. Dev., 24, 129-140, doi:10.1002/ldr.1111, 2013.

South, D. B.: Planting morphologically improvedpine seedlings to increase survival and growth, Forestry and Wildlife Research Series, No. 1, Alabama Agricultural Experiment Station, Auburn University, Alabama, 12 pp., 2000.

Srinivasarao, C. H., Venkateswarlu, B., Lal, R., Singh, A. K., Kundu, S., Vittal, K. P. R., Patel, J. J., and Patel, M. M.: Longterm manuring and fertilizer effects on depletion of soil organic carbon stocks under pearl millet-cluster bean-castor rotation in Western India, Land Degrad. Dev., 25, 173-183, 2013.

Stakman, W. P., Valk, G. A., and Van der Harst, G. G.: Determination of soil moisture retention curves. I. Sand-box apparatus. Range pF 0 to 2.7. I.C.W., 19 pp. 1969.

Tejada, M. and Gonzalez, J. L.: Effects of the application of a compost originating from crushed cotton gin residues on wheat yield under dryland conditions, Eur. J. Agron., 19, 357-368, 2013.

Thornes, J. B.: The interaction of erosional and vegetation dynamics in land degradation: spatial outcomes, edited by: Thornes, J. B., Vegetation and Erosion, Wiley, New York, 41-54, 1990.

Tongway, D. J. and Ludwing, J. A.: Rehabilitation of Semiarid Landscape in Australia, I, Restoring productive soil patches, Restor. Ecol., 4, 388-397, 1996.

Vallejo, V. R., Bautista, S., and Cortina, J.: Restoration for soil protection after disturbance. Life and Ecosystem in the Mediterranean, edited by: Trabaud, L., WIT Press, Southampton, United Kingdom, 2000.

Wahrmund, U., Hekleau, H., Röser, M., Kästener, A., Vitek, E., Ehrendorfer, F., and Bernhard von Hagen, K.: A molecular phylogeny reveals frequent changes of growth form in Carlina (Asteraceae), International Association for Plant Taxonomy, 59, 367-378, 2010.

Whisenant, S. G.: Repairing Damage Windlands, Cambridge University Press, Cambridge, United Kingdom, 1999.

Willaarts, B. A., Oyonarte, C., Muñoz-Rojas, M., Ibáñez, J. J., and Aguilera, P. A.: Environmental Factors Controlling Soil Organic Carbon Stocks in Two Contrasting Mediterranean Climatic Areas of Southern Spain, Land Deg. Dev., 27, 603-611, doi:10.1002/ldr.2417, 2016.

Woods, S. R., Fehmi, J. S., and Backer, D. M.: An assessment of revegetation treatments following removal of invasive Pennisetum ciliare (buffelgrass), J. Arid Environ., 87, 168-175, 2012.

Young, I., Renault, S., and Markham, J.: Low levels of organic amendments improves fertility and plant cover on non-acid generating gold mine tailings, Ecol. Eng, 74, 250-557, 2015. 